\title{
Obesity is associated with severe disease and mortality in patients with coronavirus disease 2019 (COVID-19): a meta-analysis
}

\author{
Zixin Cai ${ }^{\dagger}$, Yan Yang ${ }^{\dagger}$ and Jingjing Zhang ${ }^{*}$ (D)
}

\begin{abstract}
Background: The coronavirus disease 2019 (COVID-19) pandemic has led to global research to predict those who are at greatest risk of developing severe disease and mortality. The aim of this meta-analysis was to determine the associations between obesity and the severity of and mortality due to COVID-19.

Methods: We searched the PubMed, EMBASE, Cochrane Library and Web of Science databases for studies evaluating the associations of obesity with COVID-19.

Odds ratios (ORs) and 95\% confidence intervals (Cls) were calculated using random- or fixed-effects models. Metaregression analyses were conducted to estimate regression coefficients.

Results: Forty-six studies involving 625,153 patients were included. Compared with nonobese patients, obese patients had a significantly increased risk of infection.

(OR 2.73, 95\% Cl 1.53-4.87; $P^{2}=96.8 \%$ ), hospitalization (OR 1.72, 95\% Cl 1.55-1.92; $P^{2}=47.4 \%$ ), clinically severe disease (OR 3.81, 95\% Cl 1.97-7.35; $P^{2}=57.4 \%$ ), mechanical ventilation (OR 1.66, 95\% Cl 1.42-1.94; $P^{2}=41.3 \%$ ), intensive care unit (ICU) admission (OR 2.25, 95\% Cl 1.55-3.27; $\left.P^{2}=71.5 \%\right)$, and mortality (OR 1.61, 95\% Cl 1.29-2.01; $\left.P^{2}=83.1 \%\right)$.

Conclusion: Patients with obesity may have a greater risk of infection, hospitalization, clinically severe disease, mechanical ventilation, ICU admission, and mortality due to COVID-19. Therefore, it is important to increase awareness of these associations with obesity in COVID-19 patients.
\end{abstract}

Keywords: Obesity, COVID-19, Predict, Severity, Mortality

\section{Background}

On December 31, 2019, the World Health Organization (WHO) was made aware of an outbreak involving several cases of atypical pneumonia. These cases were subsequently identified as being caused by a novel virus belonging to the coronavirus $(\mathrm{CoV})$ family, called severe acute respiratory syndrome coronavirus 2 (SARS-CoV-2)

\footnotetext{
* Correspondence: Doctorzhangjj@csu.edu.cn

${ }^{\dagger}$ Zixin Cai and Yan Yang contributed equally to this work.

National Clinical Research Center for Metabolic Diseases, Metabolic Syndrome Research Center, Key Laboratory of Diabetes Immunology,

Ministry of Education, and Department of Metabolism and Endocrinology,

The Second Xiangya Hospital of Central South University, Changsha 410011, Hunan, China
}

\section{$\triangle B M C$}

C C The Author(s). 2021 Open Access This article is licensed under a Creative Commons Attribution 4.0 International License, which permits use, sharing, adaptation, distribution and reproduction in any medium or format, as long as you give appropriate credit to the original author(s) and the source, provide a link to the Creative Commons licence, and indicate if changes were made. The images or other third party material in this article are included in the article's Creative Commons licence, unless indicated otherwise in a credit line to the material. If material is not included in the article's Creative Commons licence and your intended use is not permitted by statutory regulation or exceeds the permitted use, you will need to obtain permission directly from the copyright holder. To view a copy of this licence, visit http://creativecommons.org/licenses/by/4.0/. The Creative Commons Public Domain Dedication waiver (http://creativecommons.org/publicdomain/zero/1.0/) applies to the data made available in this article, unless otherwise stated in a credit line to the data. national public health emergency due to infections caused by SARS-CoV-2. On February 20, 2020, the WHO officially named the disease caused by SARSCoV-2 coronavirus disease 2019 (COVID-19) [2, 3]. COVID-19 has posed a global health threat, causing an ongoing pandemic in many countries and territories, with approximately $6,287,771$ confirmed COVID-19 cases and 379,941 deaths [4] as of June 3, 2020. The number of COVID-19 cases has been rising worldwide, and there is increasing global concern about this outbreak [5]. 
WHO global estimates indicate that $39 \%$ of adults are overweight and 13\% are obese [6]. Obesity is an increasing worldwide health concern and is regarded as a critical risk factor for various infections, postinfection complications and mortality from severe infections [7]. Obesity has been shown to have deleterious effects on host immunity, which is the primary cause of an increased risk of infection, especially severe infection [7, 8]. Obesity has also been shown to affect lung function in multiple ways that are related to mechanical and inflammatory factors, making obese individuals more likely to suffer from respiratory symptoms and progress to respiratory failure [9].

Accumulating evidence suggests that the group of patients who develop severe COVID-19 may have a higher proportion of obesity than the group with non-severe COVID-19; in some reports, the difference was significant [10-13]. However, a lack of information regarding the global prevalence of obesity in individuals with COVID-19 remains. Investigating the influence of obesity on COVID-19 is of scientific interest. This investigation aimed to review the relationship between obesity and COVID-19. In doing so, we aim to enhance public awareness of the association between obesity and COVID-19. Furthermore, highlighting the possible associations between obesity and COVID-19 could guide those working to control the COVID-19 pandemic.

\section{Methods}

\section{Literature search}

The Preferred Reporting Items for Systematic Reviews and Meta-Analyses of Individual Participant Data (PRISMA-IPD) statement was followed for the performance and reporting of this meta-analysis [14]. Our metaanalysis focused on the relationships between obesity and the mortality due to and severity of COVID-19.

PubMed, EMBASE, the Cochrane Library and Web of Science were carefully searched from inception to January 2021 for the terms "COVID-19" and "novel coronavirus" combined with the terms "obesity" and "BMI" as index words. Two investigators ( $\mathrm{ZC}$ and $\mathrm{YY}$ ) independently reviewed the identified abstracts and selected articles for full review. Disagreements were resolved by a third investigator (JZ). The search strategy is described in a supplementary file (Supplementary File 1).

\section{Inclusion and exclusion criteria}

The inclusion criteria were as follows: (1) patients in the studies had confirmed COVID-19; (2) the body mass index (BMI) values were provided; (3) the comorbidities and severity of disease were provided; and (4) the studies were published in English. The exclusion criteria were as follows: (1) case reports, reviews, letters or nonhuman studies; (2) studies written in a language other than
English; and (3) studies with insufficient information. Two investigators (ZC and YY) independently selected studies for inclusion, and disagreements were resolved by a third investigator (JZ).

\section{Data extraction}

Data extraction was independently conducted by two authors (ZC and YY) using a standardized data collection form that included the author, year, country, patients, BMI values, and outcomes (infection, hospitalization, severe disease, mechanical ventilation, intensive care unit (ICU) admission, and mortality). The characteristics of these studies are shown in Table 1.

\section{Data synthesis and statistical analysis}

All analyses and plots were performed and generated using STATA software (version 12.0, STATA Corp, College Station, TX, USA). Forest plots were used to illustrate the association between obesity and COVID-19 in the selected studies. We pooled the data and calculated the odds ratios (ORs) and 95\% confidence intervals (CIs) for dichotomous outcomes, including infection, hospitalization, severe disease, mechanical ventilation, ICU admission, and mortality. The results of the included studies were assessed with random- or fixedeffects models. The $I^{2}$ statistic was used to assess the magnitude of heterogeneity-25, 50, and $75 \%$ represented low, moderate, and high degrees of heterogeneity, respectively. The choice of the appropriate model was based on the results; a fixed-effects model (inverse variance) was used to pool the data if $I^{2}$ was $<50 \%$, and a random-effects model (DerSimonian-Laird) was used if $I^{2}$ was $>50 \%$ [15]. Funnel plots were used to screen for potential publication bias. To determine the robustness of the results, a sensitivity analysis was conducted with sequential elimination of each study from the pool. The threshold of statistical significance was set to 0.05 .

\section{Results}

\section{Selected studies and baseline characteristics}

Overall, 2874 articles of interest were identified in the initial electronic database searches. A total of $1807 \mathrm{du}-$ plicate documents were identified. Of these, 285 full-text articles were considered potentially relevant and further assessed for eligibility. After reviewing the titles and abstracts, 239 articles were excluded because they were not written in English, were case series/reports or reviews, did not contain the full text, or had no reported data. The remaining 46 studies were carefully evaluated in detail; these 46 studies met the inclusion criteria and were finally included (Fig. 1). Of the included studies, 18 reported mortality, 10 reported ICU admission, 8 reported the development of severe disease, 7 reported mechanical ventilation, 7 reported infections, and 5 reported 
Table 1 Characteristics of available studies on the relationship between obesity and COVID-19

\begin{tabular}{|c|c|c|c|c|c|c|}
\hline Number & Author & Year & Country & Patients & BMI & Outcomes \\
\hline 1 & Natasha $\mathrm{N}$ & 2020 & USA & 238 & 30 & $1.7(1.1-2.8)$ for mortality \\
\hline 2 & Céline & 2020 & France & 347 & 30 & $3.0(1.0-8.7)$ for severity \\
\hline 3 & Nikroo & 2020 & USA & 363 & NA & $\begin{array}{l}1.23(0.77-1.98) \text { for mechanical ventilation; } 1.26(0.79-1.98) \text { for ICU; } \\
1.03(0.51-2.09) \text { for mortality }\end{array}$ \\
\hline 4 & Edgar & 2020 & Mexico & 140 & NA & $2.3265(1.0133-5.3415)$ for ICU \\
\hline 5 & Bo & 2020 & USA & 58 & 30 & $1.98(0.56-7.72)$ for hospitalisation; $2.04(0.5-8.4)$ for mortality \\
\hline 6 & Marie E & 2020 & USA & 531 & 30 & 1.9 (1.1-3.3) for hospitalisation \\
\hline 7 & Geehan & 2020 & USA & 463 & 40 & $2.0(1.4-3.6)$ for ICU \\
\hline 8 & Eduardo & 2020 & Mexico & 32,583 & NA & $6.92(5.54-8.65)$ for infection \\
\hline 9 & Michael & 2020 & USA & 1000 & 30 & $1.2911(0.9478-1.7587)$ for ICU \\
\hline 10 & Xiao & 2020 & USA & NA & NA & $0.94(0.86,1.02)$ for mortality \\
\hline 11 & Mark & 2020 & UK & 387,109 & 30 & $1.97(1.61,2.42)$ for hospitalisation \\
\hline 12 & Philip & 2020 & USA & 50 & NA & $14.4(2.7052-76.6517)$ for severity \\
\hline 13 & Juan & 2020 & Bolivia & 107 & NA & $12.125(1.690-86.948)$ for mortality \\
\hline 14 & Stefano & 2020 & Italy & 132 & 30 & $1.526(1.243-1.874)$ for ICU \\
\hline 15 & J.M. & 2020 & Spain & 172 & 30 & $4.725(1.6143-13.8302)$ for ICU \\
\hline 16 & Omar & 2020 & Mexico & 177,133 & NA & $1.5790(1.5358-1.6235)$ for infection \\
\hline 17 & Nicole & 2020 & USA & 928 & NA & $0.99(0.58-1.71)$ for mortality \\
\hline 18 & Kaveh & 2020 & USA & 770 & 30 & $\begin{array}{l}1.76(1.24-2.48) \text { for ICU; } 1.72(1.22-2.44) \text { for mechanical ventilation; } \\
1.15(0.62-2.14) \text { for mortality }\end{array}$ \\
\hline 19 & Luca & 2020 & Italy & 92 & 30 & $\begin{array}{l}4.19(1.36-12.89) \text { for mechanical ventilation; } 11.65(3.88-34.96) \text { for } \\
\text { ICUs; } 0.27(0.03-2.05) \text { for mortality }\end{array}$ \\
\hline 20 & Eboni G & 2020 & USA & 3626 & 30 & $1.43(1.20-1.71)$ for hospitalization \\
\hline 21 & Frederick $S$ & 2020 & USA & 105 & 30 & $1.2908(0.5936-2.8071)$ for severity \\
\hline 22 & Eyal & 2020 & USA & 3406 & 40 & $1.6(1.2-2.3)$ for the older population mortality \\
\hline 23 & Andrea & 2020 & Italy & 233 & NA & 3.04 (1.42-6.49) for mortality \\
\hline 24 & Annemarie B1 & 2020 & UK & 20,133 & NA & 1.33 (1.19 to 1.49$)$ for mortality \\
\hline 25 & Qingxian & 2020 & China & 383 & 28 & $3.4(1.4-8.26)$ for severity \\
\hline 26 & Jerry $Y$ & 2020 & USA & 67 & 30 & $0.8000(0.1784-3.5872)$ for ICU \\
\hline 27 & Markos & 2020 & USA & 103 & 30 & $6.85(1.05-44.82)$ for mechanical ventilation; $2.65(0.64-10.95)$ for ICU \\
\hline 28 & Arthur & 2020 & France & 124 & 30 & $3.45(0.83-14.31)$ for mechanical ventilation \\
\hline 29 & Simon & 2020 & UK & 3802 & 30 & $1.41(1.04-1.91)$ for infection \\
\hline 30 & Kenneth I & 2020 & China & 214 & 25 & $6.32(1.16-34.54)$ for severity \\
\hline 31 & Ling & 2020 & China & 323 & 30 & $1.2514(0.3735-4.1935)$ for severity \\
\hline 32 & Leonidas & 2020 & USA & 200 & 35 & $3.78(1.45-9.83)$ for mortality \\
\hline 33 & Christopher & 2020 & USA & 5279 & 30 & 1.8 (1.47 to 2.2 ) for hospitalisation \\
\hline 34 & Rui & 2020 & China & 202 & 28 & $9.219(2.731-31.126)$ for severity \\
\hline 35 & Feng & 2020 & China & 150 & 25 & $2.91(1.31-6.47)$ for severity \\
\hline 36 & Matteo & 2020 & Italy & 482 & 30 & $4.96(2.53-9.74)$ for ICU; 12.1 (3.25-45.1) for mortality \\
\hline 37 & Malcolm & 2020 & France & 83 & 30 & $6.7879(2.5923-17.7739)$ for infection \\
\hline 38 & Mohamed & 2020 & USA & 504 & 30 & $1.3(1.0-1.7)$ for mortality; $2.4(1.5-4.0)$ for mechanical ventilation \\
\hline 39 & Yudong Peng & 2020 & China & 244 & 24 & $8.5853(4.1817-17.6260)$ for mortality \\
\hline 40 & Ming Deng & 2020 & China & 65 & 28 & $14(2.0799-94.2358)$ for severity \\
\hline 41 & Marta Crespo & 2020 & Spain & 16 & NA & $5(0.5842-42.7971)$ for mortality \\
\hline 42 & Danielle Toussie & 2020 & USA & 338 & 30 & $3.0(1.6-5.6)$ for infection \\
\hline
\end{tabular}


Table 1 Characteristics of available studies on the relationship between obesity and COVID-19 (Continued)

\begin{tabular}{lllllll}
\hline Number & Author & Year & Country & Patients & BMI & Outcomes \\
\hline 43 & Michelle Elias & 2020 & France & 1216 & 30 & $3.31(1.90$ to 5.77) for infection \\
44 & Sudham Chand & 2020 & USA & 300 & 30 & $1.35(0.88,2.06)$ for mortality \\
45 & Justin S. Brandt & 2020 & USA & 183 & 30 & $0.875(0.3466-2.2088)$ for infection \\
46 & Astrid Lievre & 2020 & France & 1289 & 30 & $1.1461(0.8165-1.6088)$ for mortality \\
\hline
\end{tabular}

hospitalization. Twenty-one studies originated from the USA, 7 originated from China, 5 originated from France, 4 originated from Italy, 3 originated from the UK, 3 originated from Mexico, 2 originated from Spain, and one originated from Bolivia (Table 1). Diagnosis of COVID19 and definitions of obesity in the included studies were shown in Table 2. Definition of severe COVID-19 used in each study was shown in Table 3 . Study design in the included studies were shown in Supplementary Table 1.

\section{Viral infection}

To assess the impact of obesity on viral infection, we included 7 studies [16-22] with 215,338 subjects. The data indicated that obesity significantly increased the risk of viral infection $\left(\mathrm{OR}=2.73,95 \%\right.$ CI $1.53-4.87 ; I^{2}=96.8 \%$; Fig. 2).

\section{Risk of hospitalization}

To assess the impact of obesity on the risk of hospitalization, we included 5 studies [23-27] involving 396,603 subjects. The data indicated that obesity increased the risk of hospitalization $(\mathrm{OR}=1.72,95 \% \mathrm{CI}$ $1.55-1.92 ; I^{2}=47.4 \%$; Fig. 3 ).

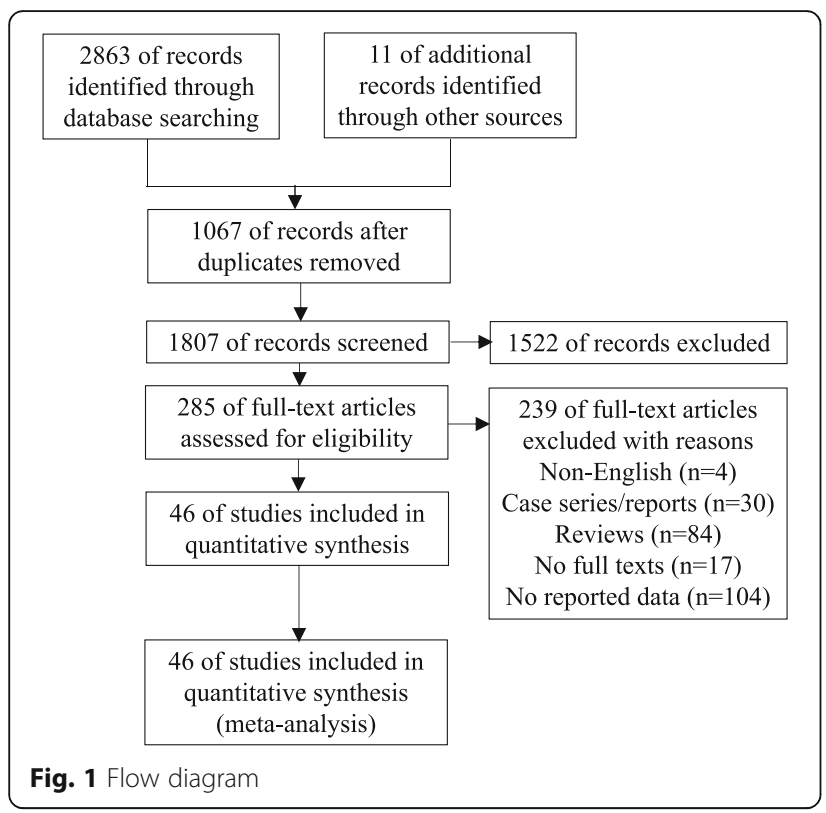

Risk of severe disease

To assess the impact of obesity on the risk of severe disease, we included 8 studies [10-12, 28-32] involving 1839 subjects. The data indicated that obesity was associated with an increased risk of severe disease $(\mathrm{OR}=$ 3.81, 95\% CI 1.97-7.35; $I^{2}=57.4 \%$; Fig. 4).

\section{Use of mechanical ventilation}

To assess the impact of obesity on mechanical ventilation use, we included 7 studies [33-39] involving 2088 subjects. The data indicated that obesity was associated with the use of mechanical ventilation $(\mathrm{OR}=1.66,95 \%$ CI 1.42-1.94; $I^{2}=41.3 \%$; Fig. 5).

\section{Risk of ICU admission}

To assess the impact of obesity on the risk of ICU admission, we included 10 studies [33, 35-37, 40-45] involving 3652 subjects. The data indicated that obesity was closely associated with the risk of ICU admission $\left(\mathrm{OR}=2.25\right.$, 95\% CI 1.55-3.27; $I^{2}=71.5 \%$; Fig. 6).

\section{Risk of mortality}

To assess the impact of obesity on the risk of mortality, we included 18 studies [23, 33, 35, 36, 39, 44, 46-56] [57] involving 29,305 subjects. The data indicated that obesity was significantly associated with the risk of mortality $\left(\mathrm{OR}=1.61,95 \%\right.$ CI $1.29-2.01 ; I^{2}=83.1 \%$; Fig. 7). Univariate meta-regression analysis of possible confounders of COVID-19 outcomes in patients with and without obesity was shown in Table 4.

\section{Publication bias and sensitivity analysis}

We found no potential publication bias in the studies included in the meta-analysis (Fig. 8). The sensitivity analysis suggested that our results are stable and reliable (Fig. 9).

\section{Discussion}

We conducted this meta-analysis to determine whether obesity is a predictor of the COVID-19 severity of and mortality. In the present review, we included 46 articles involving 625,153 patients. Obese patients had a significantly increased risk of infection, hospitalization, severe disease mechanical ventilation, ICU admission, and mortality relative to patients of normal weight. 
Table 2 Diagnosis of COVID-19 and definitions of obesity in the included studies

\begin{tabular}{|c|c|c|}
\hline Author & Diagnosis of COVID-19 & Definitions of obesity \\
\hline Philip Zachariah & RT-PCR & $\begin{array}{l}\text { CDC's child and teen body mass } \\
\text { index }\end{array}$ \\
\hline Eduardo Hernández-Gardu & RT-PCR & NA \\
\hline $\begin{array}{l}\text { Omar Yaxmehen Bello- } \\
\text { Chavolla }\end{array}$ & SARS-CoV-2 testing and signs of breathing difficulty or deaths & NA \\
\hline Simon de Lusignan & RT-PCR & $\mathrm{BMI} \geq 30 \mathrm{~kg} / \mathrm{m} 2$ \\
\hline Malcolm Lemyze & $\begin{array}{l}\text { RT-PCR and typical clinical presentation and imaging features on CT } \\
\text { scan }\end{array}$ & $\mathrm{BMI}>30 \mathrm{~kg} / \mathrm{m} 2$ \\
\hline Marie E & RT-PCR & $\mathrm{BMI} \geq 30 \mathrm{~kg} / \mathrm{m} 2$ \\
\hline Mark Hamer & RT-PCR & obese $\geq 30 \mathrm{~kg} / \mathrm{m} 2$ \\
\hline Eboni G & RT-PCR & $\mathrm{BMI} \geq 30 \mathrm{~kg} / \mathrm{m} 2$ \\
\hline Christopher M Petrilli & RT-PCR & $\mathrm{BMI} \geq 30 \mathrm{~kg} / \mathrm{m} 2$ \\
\hline Céline Louapre & RT-PCR & $\mathrm{BMI}>30 \mathrm{~kg} / \mathrm{m} 2$ \\
\hline Frederick S & RT-PCR & $\mathrm{BMI}>30 \mathrm{~kg} / \mathrm{m} 2$ \\
\hline QingxianCai & RT-PCR & $\mathrm{BMI} \geq 28 \mathrm{~kg} / \mathrm{m} 2$ \\
\hline Kenneth I & high-throughput sequencing or RT-PCR & $\mathrm{BMI} \geq 25 \mathrm{~kg} / \mathrm{m} 2$ \\
\hline Ling $\mathrm{Hu}$ & $\begin{array}{l}\text { clinical presentation, characteristic CT image, and/or leukopenia and } \\
\text { lymphopenia }\end{array}$ & $\mathrm{BMI}>30 \mathrm{~kg} / \mathrm{m} 2$ \\
\hline Rui Huang & RT-PCR & $\mathrm{BMI} \geq 28 \mathrm{~kg} / \mathrm{m} 2$ \\
\hline Nikroo Hashemi & RT-PCR & NA \\
\hline Stefano Di Bella & RT-PCR & $\mathrm{BMI} \geq 30 \mathrm{~kg} / \mathrm{m} 2$ \\
\hline Kaveh Hajifathalian & RT-PCR & $\mathrm{BMI}>30 \mathrm{~kg} / \mathrm{m} 2$ \\
\hline Luca Busetto & RT-PCR & $\mathrm{BMI} \geq 30 \mathrm{~kg} / \mathrm{m} 2$ \\
\hline Markos Kalligeros & NA & $\mathrm{BMI} \geq 30 \mathrm{~kg} / \mathrm{m} 2$ \\
\hline rthur Simonnet & RT-PCR & $\mathrm{BMI}>30 \mathrm{~kg} / \mathrm{m} 2$ \\
\hline Mohamed Nakeshbandi & RT-PCR & $\mathrm{BMI} \geq 30 \mathrm{~kg} / \mathrm{m} 2$ \\
\hline Edgar & RT-PCR & NA \\
\hline Geehan Suleyman & NA & $\mathrm{BMI} \geq 40 \mathrm{~kg} / \mathrm{m} 2$ \\
\hline Michael G Argenziano & RT-PCR & $\mathrm{BMI}>30 \mathrm{~kg} / \mathrm{m} 2$ \\
\hline J.M. Urra & RT-PCR & $\mathrm{BMI}>30 \mathrm{~kg} / \mathrm{m} 2$ \\
\hline Matteo Rottoli & RT-PCR & $\mathrm{BMI} \geq 30 \mathrm{~kg} / \mathrm{m} 2$ \\
\hline Jerry Y. Chao & RT-PCR & $\mathrm{BMI} \geq 30 \mathrm{~kg} / \mathrm{m} 2$ \\
\hline Natasha N. Pettit & RT-PCR & $\mathrm{BMI}>30 \mathrm{~kg} / \mathrm{m} 2$ \\
\hline Bo Wang & RT-PCR & $\mathrm{BMI}>30 \mathrm{~kg} / \mathrm{m} 2$ \\
\hline Xiao Wu & NA & NA \\
\hline $\begin{array}{l}\text { Juan Pablo Escalera- } \\
\text { Antezana }\end{array}$ & RT-PCR & NA \\
\hline Nicole M Kuderer & NA & NA \\
\hline Eyal Klang & RT-PCR & $\mathrm{BMI}>30 \mathrm{~kg} / \mathrm{m} 2$ \\
\hline Andrea Giacomelli & RT-PCR & $\mathrm{BMI} \geq 30 \mathrm{~kg} / \mathrm{m} 2$ \\
\hline Annemarie B Docherty & NA & NA \\
\hline Leonidas Palaiodimos & NA & $\mathrm{BMI} \geq 35 \mathrm{~kg} / \mathrm{m} 2$ \\
\hline Yudong Peng & RT-PCR & $\mathrm{BMI} \geq 24 \mathrm{~kg} / \mathrm{m} 2$ \\
\hline Ming Deng & RT-PCR & NA \\
\hline Marta Crespo & NA & NA \\
\hline Danielle Toussie & RT-PCR & $\mathrm{BMI}>30 \mathrm{~kg} / \mathrm{m} 2$ \\
\hline
\end{tabular}


Table 2 Diagnosis of COVID-19 and definitions of obesity in the included studies (Continued)

\begin{tabular}{lll}
\hline Author & Diagnosis of COVID-19 & Definitions of obesity \\
\hline Michelle Elias & RT-PCR & BMI $\geq 30 \mathrm{~kg} / \mathrm{m} 2$ \\
Sudham Chand & RT-PCR & BMI $\geq 30 \mathrm{~kg} / \mathrm{m} 2$ \\
Justin S. Brandt & RT-PCR & BMI $\geq 30 \mathrm{~kg} / \mathrm{m} 2$ \\
Astrid Lie 'vre & RT-PCR & BMI $\geq 30 \mathrm{~kg} / \mathrm{m} 2$ \\
\hline
\end{tabular}

Mechanisms underlying the association of obesity with the severity of and mortality due to COVID-19

The first mechanism underlying the investigated associations involves adipose tissue (AT). Obesity, usually defined as a BMI $>30 \mathrm{~kg} / \mathrm{m}^{2}$, is characterized by visceral AT expansion and inflammation [58]. Adipocytes secrete a plenty of factors and hormones that affect many organ systems, including the lungs. Underlying mechanisms of obesity on the severity of COVID-19 may involve abnormalities in the production of adipokines by $\mathrm{AT}$, for example, leptin and adiponectin [59, 60]. Leptin as a cytokine can have pro-inflammatory functions that influences both innate and adaptive immune responses by stimulating the production (interleukin (IL)-2 and tumour necrosis factor-alpha (TNF- $\alpha)$ ) and suppressing the secretion of IL-4 and IL-5 [61]. In contrast, adiponectin is adipokine that exerts anti-inflammatory actions that inhibits (TNF- $\alpha$, IL-6, and nuclear factor- $\mathrm{KB}$ ) and induces (IL-10 and IL-1 receptor antagonist) [61]. Leptin concentrations are increased, whereas adiponectin levels are decreased in obesity $[62,63]$. The imbalance between leptin and adiponectin may result in the development of dysregulated immune response [64].

The second mechanism involves angiotensin-converting enzyme-2 (ACE-2), COVID-19 utilizes the host ACE2 for binding and entry into host cells. The ACE2 expression is highest in AT. The increase of AT in obese patients increases the expression level of ACE2, which may increase their susceptibility to COVID-19 [65].
Third, impaired lung function and higher level of proinflammatory Cytokines may collaborate to promote the development of respiratory viral infections in patients with obesity. Obesity reduces thoracic wall compliance, resulting in a reduction in functional residual capacity and favor the development of atelectasis $[9,66]$.

Finally, obesity results in physiological lung alterations, such as decreased functional residual capacity and hypoxemia [67]. In addition, obstructive sleep apnoea hypopnea syndrome (OSAHS) increases adverse outcomes of COVID-19 [68]. The etiology of OSAHS is complex, and obesity is one of the main causes of the syndrome. OSAHS is related to obesity. About 60-90\% of patients with OSAHS are overweight [69], and the incidence rates of OSAHS in the obese patients is near twice that in normal-weight patients [70].

All of the above mechanisms can reasonably explain how obesity increases COVID-19 severity and mortality.

Implications for strategies to treat patients with obesity Obesity is a clinical predictor of adverse outcomes in COVID-19 patients; therefore, improved intensive care guidelines for patients with elevated BMI are strongly recommended. Individuals with obesity is an important risk factor for COVID-19, including infection, hospitalization, severe disease, mechanical ventilation, ICU admission, and death. Patients with obesity may require special monitoring. Therefore, obesity patients with COVID-19 require special attention. Additionally,

Table 3 Definition of severe COVID-19 used in each study

\begin{tabular}{|c|c|c|}
\hline Author & Year & Definition of a severe form of COVID-19 \\
\hline Céline Louapre & 2020 & $\begin{array}{l}\text { 7-point ordinal scale (ranging from } 1 \text { [not hospitalized with no limitations on activities] to } 7 \text { [death]) with a cut off } \\
\text { at } 3 \text { (hospitalized and not requiring supplemental oxygen) }\end{array}$ \\
\hline $\begin{array}{l}\text { Philip } \\
\text { Zachariah }\end{array}$ & 2020 & Severe diseaseas defined by the requirement for mechanical ventilation \\
\hline Frederick S & 2020 & defined as admission to the intensive care unit or death \\
\hline QingxianCai & 2020 & based on results from chest radiography, clinical examination, and symptoms \\
\hline Kenneth I & 2020 & based on the current management guideline \\
\hline Ling Hu & 2020 & based initial clinical presentation \\
\hline Rui Huang & 2020 & $\begin{array}{l}\text { according to guidelines for the diagnosisand treatment of novel coronavirus (2019-nCoV) infection by the national } \\
\text { health commission (trial version } 5 \text { ) }\end{array}$ \\
\hline Ming Deng & 2020 & $\begin{array}{l}\text { rapid decline in albumin level, the decrease in albumin was accompanied by an increase in D-dimer, which is an } \\
\text { indicator of hypercoagulation }\end{array}$ \\
\hline
\end{tabular}




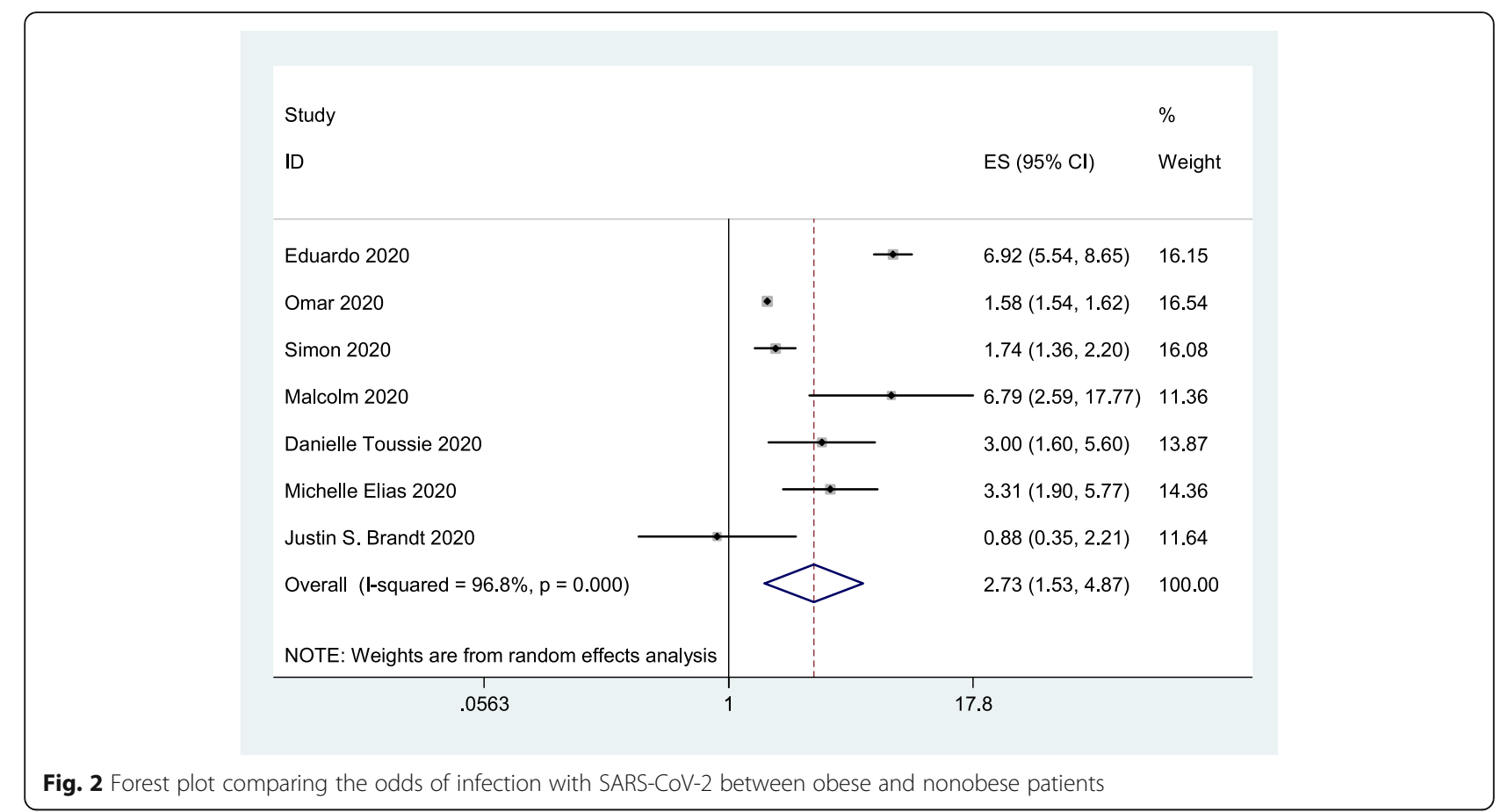

people of obesity should be offered as prioritizing for vaccination of COVID - 19.

Obesity aggravates adverse outcomes in COVID-19 patients, and the occurrence of COVID-19 also leads to an increase in obesity. The public control of the COVID-19 outbreak is mainly about controlling human contact, which affects people's behavior to a certain extent and contributes to obesity [71]. Isolation susceptibility to incidence of mental illness [72]. Experiencing loneliness can lead to cut down on physical activity [73]. Regular physical activity is important for maintaining body weight. And as economic conditions decline,

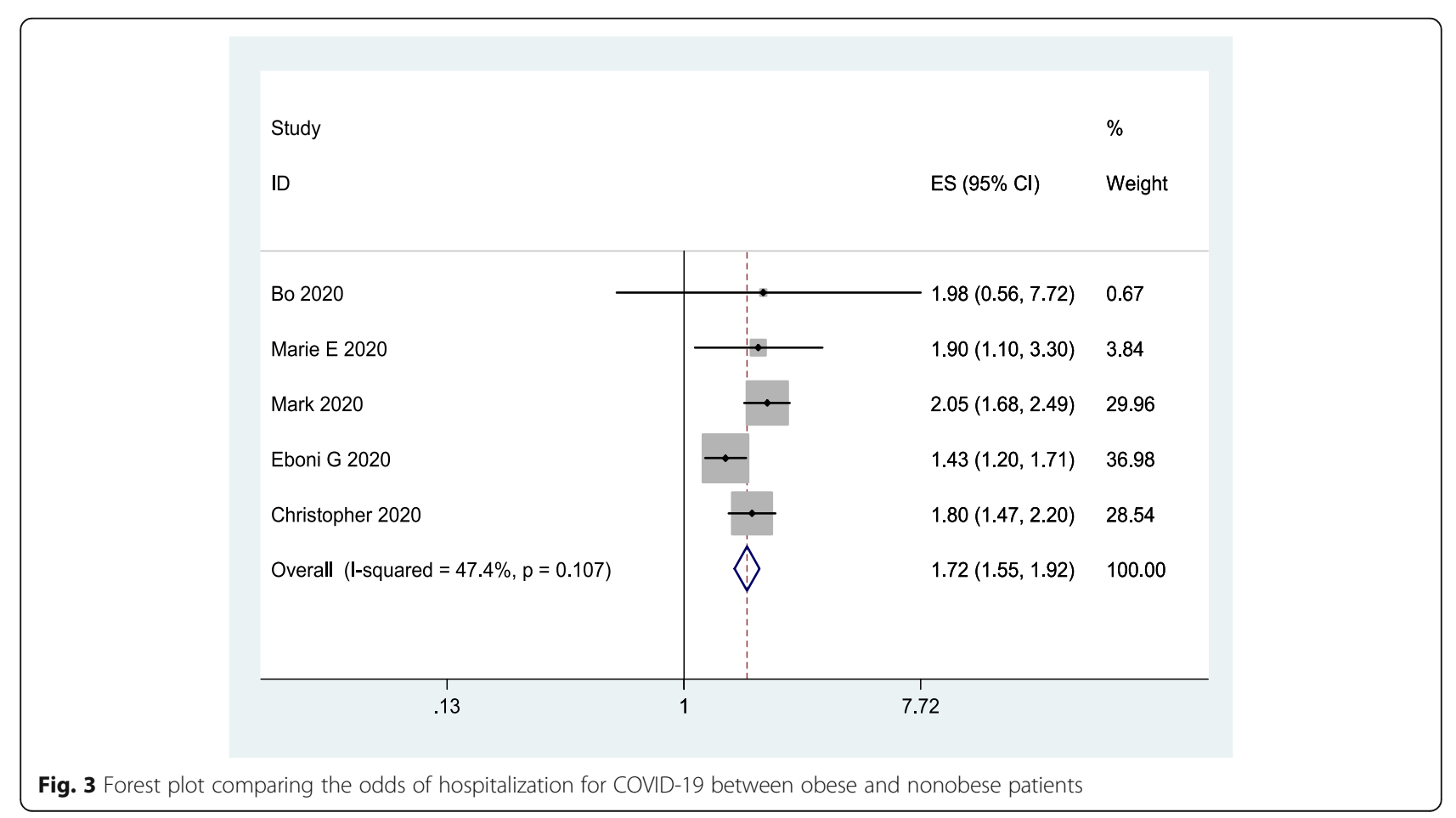




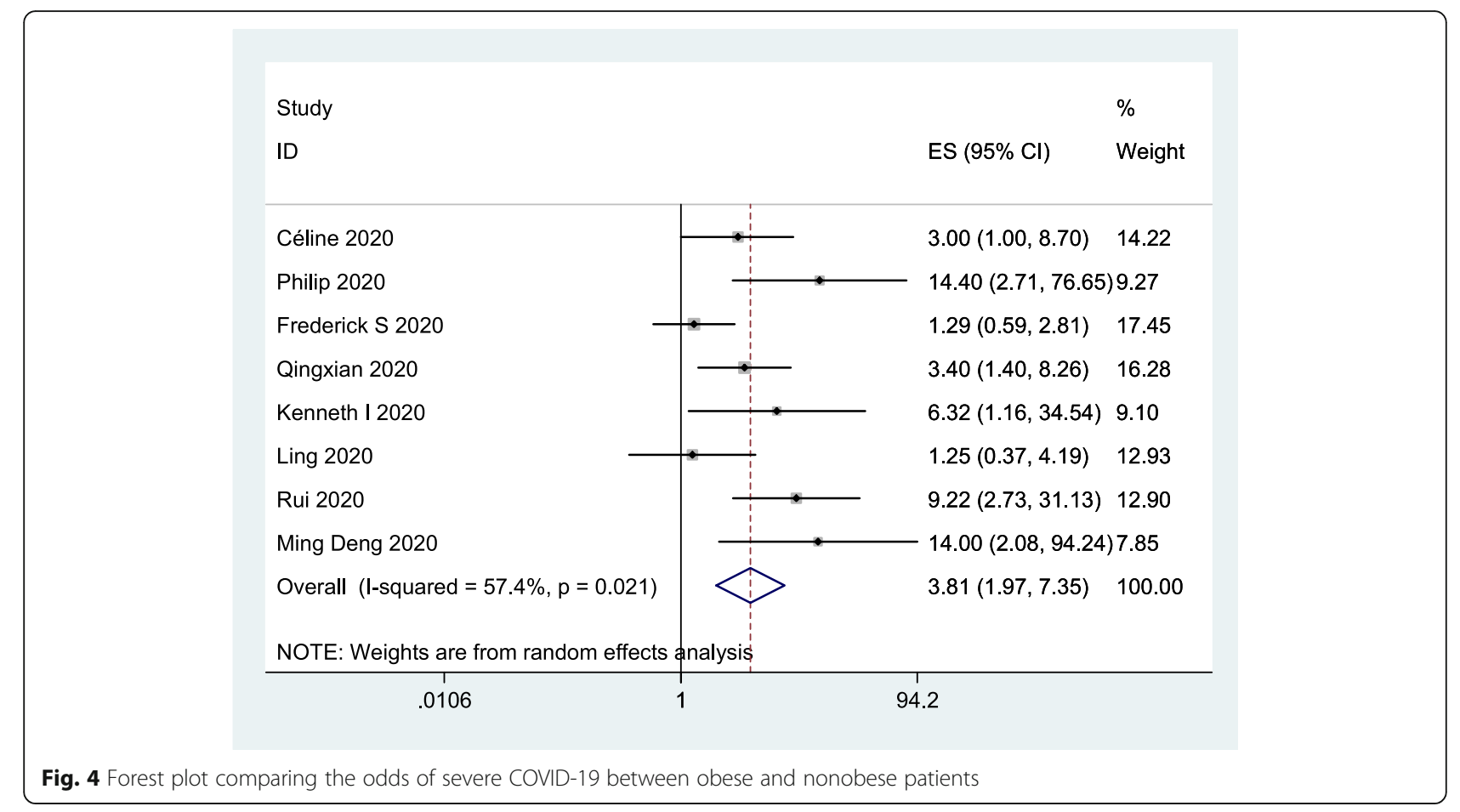

people turn to cheaper foods, which tend to be higher in calories [74]. While more and more people are cooking at home, food stored is likely to be processed to extend its shelf life. Processed foods are associated with more fat, carbohydrate and calorie intake, which is more likely to lead to weight gain than a healthy diet [75].

Preventing obesity is important. Losing weight usually involves increasing physical activity and limiting caloric intake. It is said that individuals complete $\geq 300 \mathrm{~min} /$

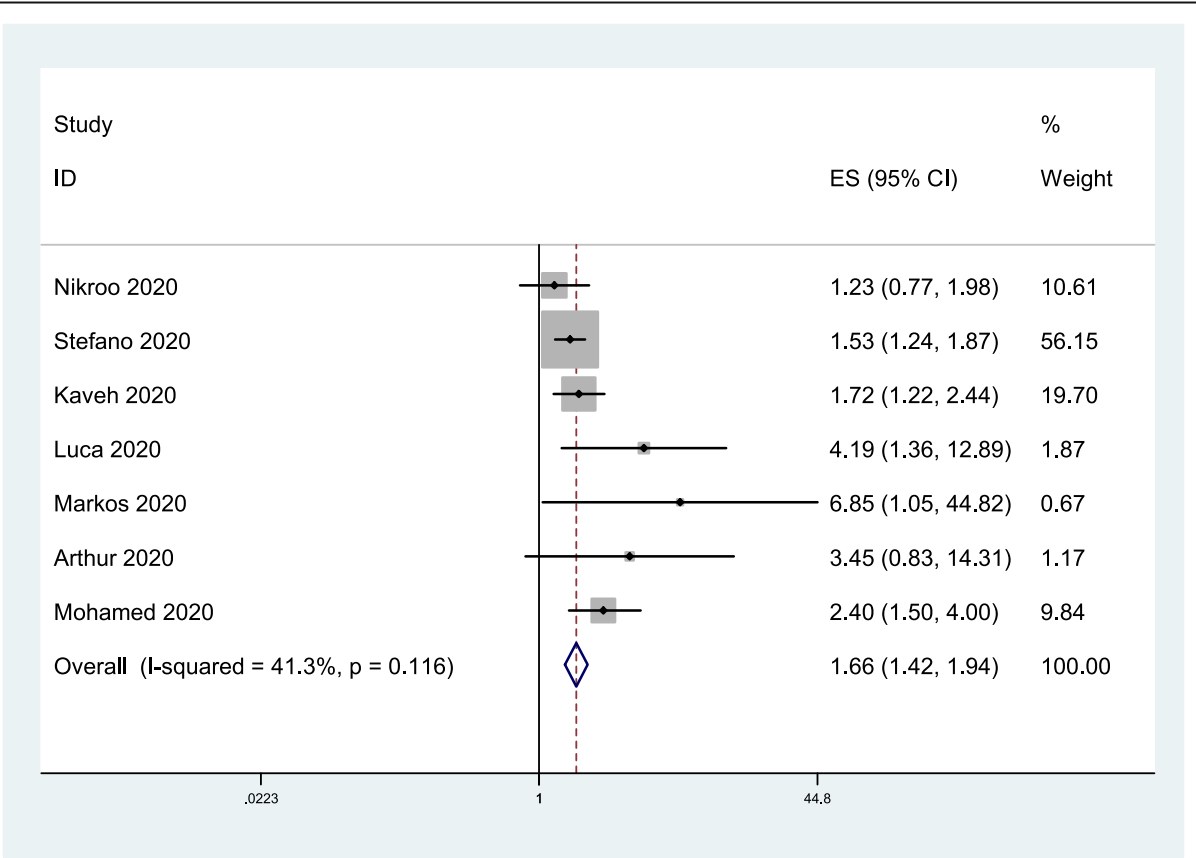

Fig. 5 Forest plot comparing the odds of mechanical ventilation due to COVID-19 between obese and nonobese patients 
Study

ID

Nikroo 2020

Edgar 2020

Geehan 2020

Michael 2020

J.M. 2020

Kaveh 2020

Luca 2020

Jerry $Y 2020$

Markos 2020

Matteo 2020

Overall (I-squared $=71.5 \%, p=0.000)$

NOTE: Weights are from random effects an alysis

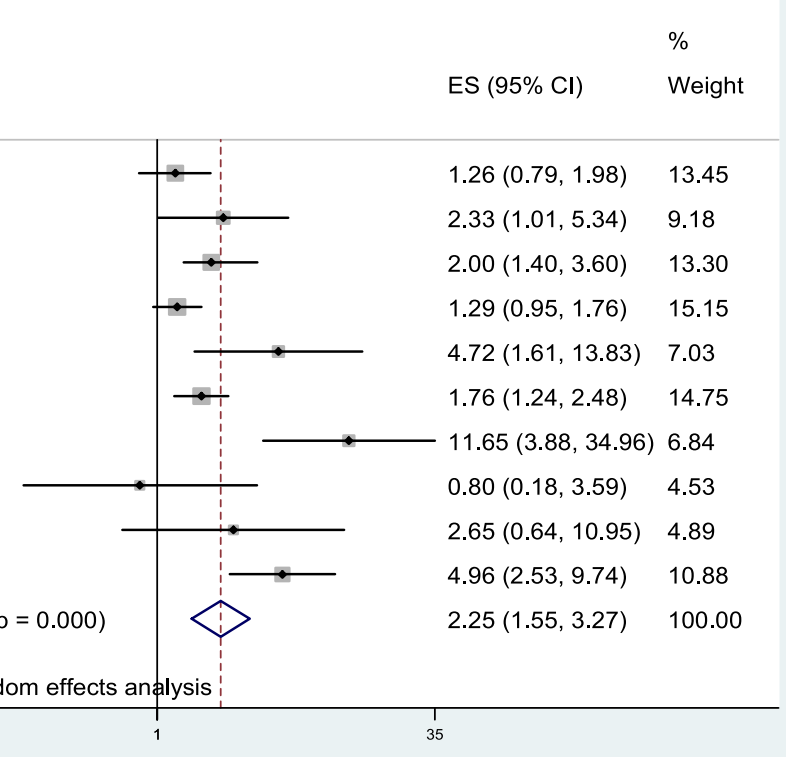

Fig. 6 Forest plot comparing the odds of ICU admission due to COVID-19 between obese and nonobese patients

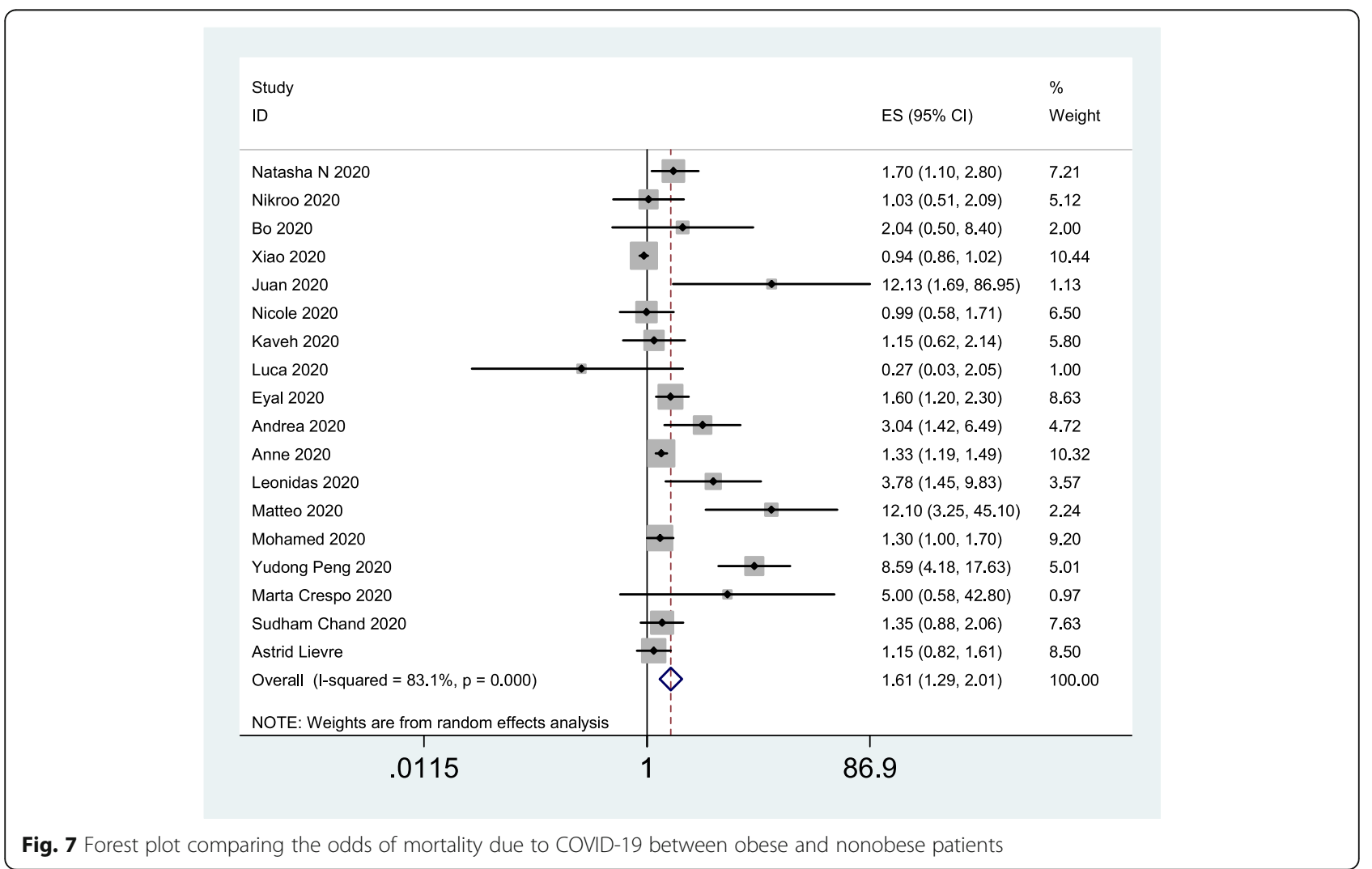


Table 4 Univariate meta-regression analysis of possible confounders of COVID-19 outcomes in patients with and without obesity

\begin{tabular}{llllll}
\hline Inor & $\exp (\mathrm{b})$ & Std. Err. & $\mathrm{t}$ & $\mathrm{P}>|\mathrm{t}|$ & [95\% Conf. Interval] \\
\hline country | & 0.58474 & 1.54184 & -0.2 & 0.844 & $0.0013373,255.6731$ \\
cons | & 6.06585 & 31.98394 & 0.34 & 0.741 & $0.0000318,1,157,460$
\end{tabular}

week of physical activity for weight maintenance [76]. People implemented a variety of weight loss strategies, including eating less, increasing physical activity, skipping meals, or taking weight-loss pills or diuretics [77]. Among those trying to lose weight, reducing calorie intake is the most common way $[78,79]$.

One study found that use of metformin was significantly associated with a reduction in COVID-19 mortality [80]. Several reasons might explain this finding. First, metformin reduces the binding of the SARS-CoV-2 to the receptor [81]. Second, metformin inhibits the mTOR signaling pathway, thus reducing SARS-CoV-2 infectivity and COVID-19 mortality [80]. Third, metformin can the inflammatory response [82]. Additionally, metformin reduces the risk of adverse outcomes in COVID-19 patients by reducing BMI and body weight [83].

Due to the extensive spread of COVID-19, enforced confinement has influenced the lives of individuals in many ways, including working behaviours, psychological factors, sedentary activities, and other harmful effects on life habits [84]. Because of increased stress and boredom, people tend to overeat, resulting in the consumption of additional energy/calories and an increased craving for food [85]. In this regard, COVID-19 has contributed to the occurrence of obesity.

\section{Theoretical and practical implications}

To the best of our knowledge, this is the first metaanalysis to comprehensively assess obesity and COVID19 outcomes (infection, hospitalization, severe disease, mechanical ventilation, ICU admission, and mortality). Obesity is a risk factor and predictor of serious disease and is a factor in the need for advanced medical care for COVID-19 patients. Basic research is needed to determine the causal relationship between obesity and adverse outcomes of COVID-19. This study has some limitations. First, some indicators, such as the risk of infection, ICU admission, and mortality, had greater degrees of heterogeneity, and subgroup analyses cannot be performed due to the small number of studies on each indicator. However, the trends were consistent across nearly all forest plots. In addition, many of the included articles did not give specific BMI values, and it is not clear how much a specific unit increase in BMI can increase the severity and mortality rate of COVID-19. Third, because this meta-analysis includes data from
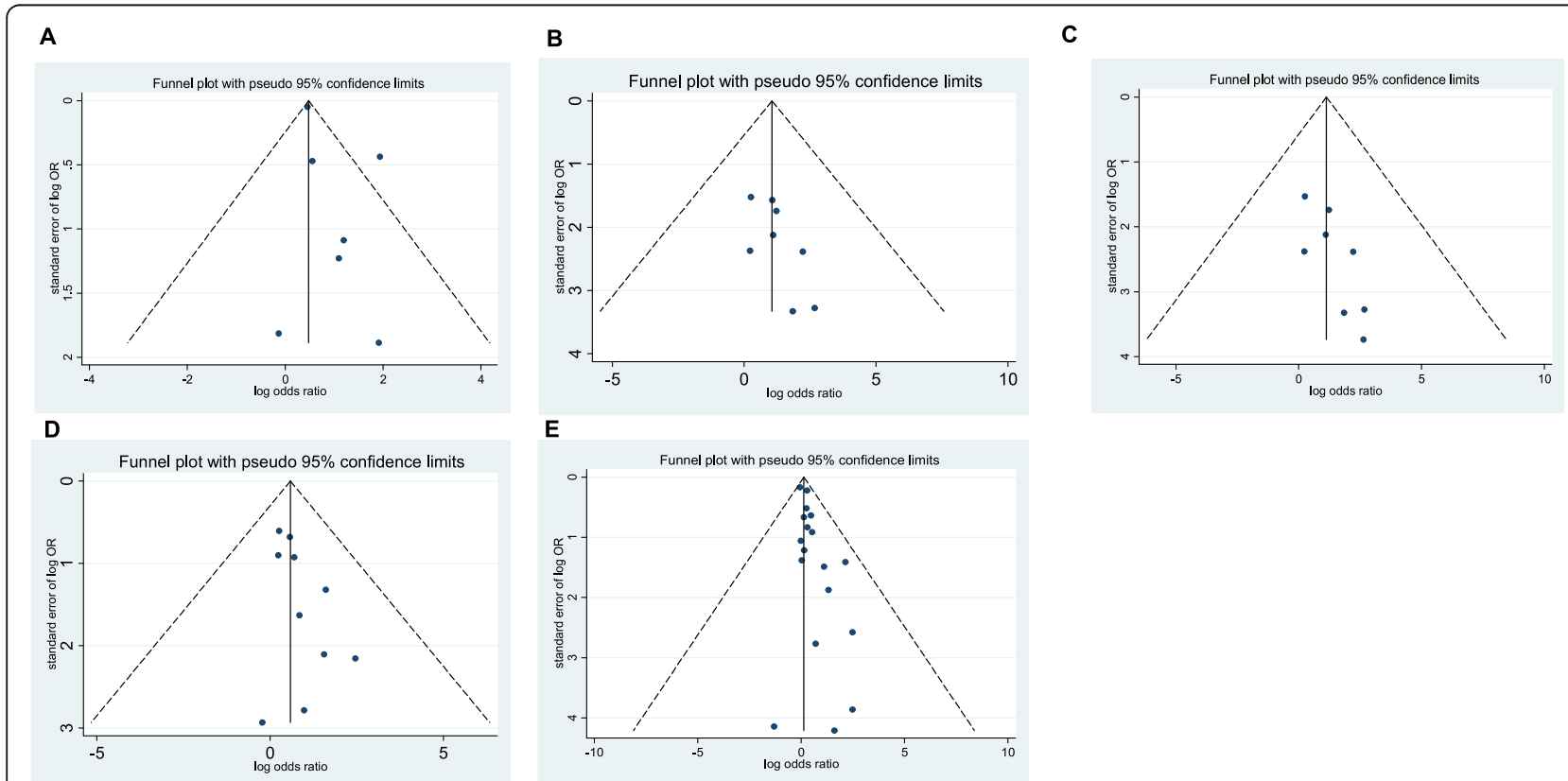

Fig. 8 Funnel plot for hospitalization (A), severe disease (B), mechanical ventilation (C), ICU admission (D), and mortality (E) between obese and non-obese patients 

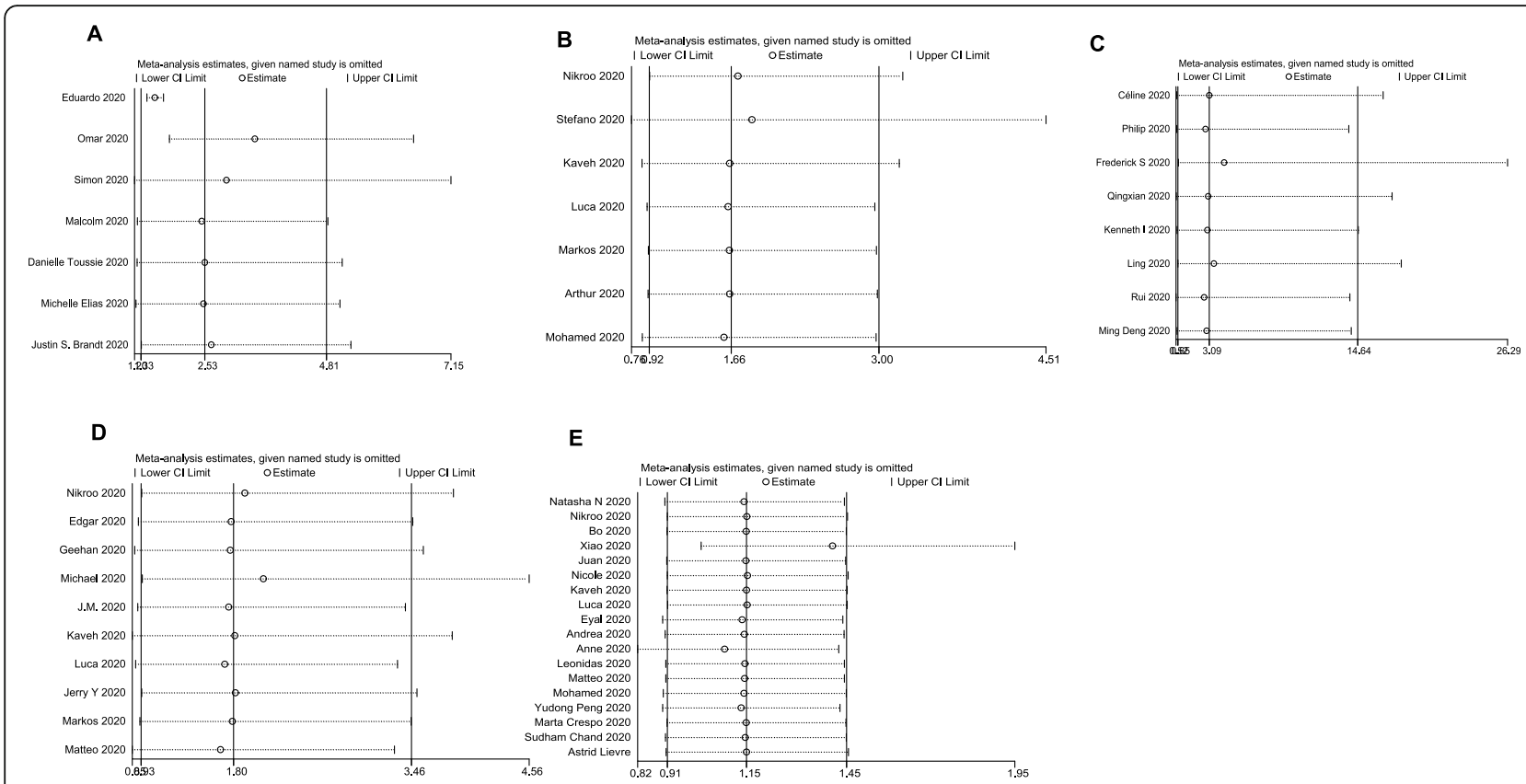

Fig. 9 Sensitivity analysis for hospitalization (A), severe disease (B), mechanical ventilation (C), ICU admission (D), and mortality (E) between obese and nonobese patients

multiple countries, the criteria for ICU admission and mechanical ventilation usage may not have been uniform. However, the decision to escalate a patient to critical care is primarily based on the judgement of clinicians, as there are no set guidelines at individual sites. Finally, because none of the studies were randomized controlled trials, the causal relationships between obesity and COVID-19 severity and mortality could not be determined.

\section{Conclusion}

Patients with obesity may have a greater risk of COVID19 infection, hospitalization, clinically severe disease, mechanical ventilation, ICU admission, and mortality. Our results may prompt clinicians to pay particular attention to obese patients when treating COVID-19.

\section{Abbreviations}

COVID-19: Coronavirus Disease 2019; ORs: Odds ratios; Cls: confidence intervals; WHO: World Health Organization; CoV: coronavirus; SARS-CoV2: severe acute respiratory syndrome coronavirus 2; PRISMA-IPD: Preferred Reporting Items for Systematic Reviews and Meta-Analyses of Individual Participant Data; BMI: body mass index; ICU: intensive care unit; AT: adipose tissue; IL: interleukin; TNF-a: tumour necrosis factor-alpha; ACE-2: angiotensinconverting enzyme-2; OSAHS: obstructive sleep apnoea hypopnea syndrome

\section{Supplementary Information}

The online version contains supplementary material available at https://doi. org/10.1186/s12889-021-11546-6.

Additional file 1. Full electronic search performed in multiple international databases.

Additional file 2: Table S1. Study design.

\section{Acknowledgments}

I am grateful to my department leaders for their great encouragement, support and help to this project.

\section{Authors' contributions}

JZ coordinated the study. ZC, YY, and JZ conceived the study, contributed to the study design, literature search, figure generation, statistical analysis, outcome synthesis and paper drafting and editing. All authors edited and approved the final version of the manuscript.

\section{Funding}

This work was supported by grants from the National Natural Science Foundation of China (82070807, 91749118, 81770775, 81730022), the Planned Science and Technology Project of Hunan Province (2017RS3015) and National key research and development program (2019YFA0801903, 2018YFC2000100)

\section{Availability of data and materials}

The datasets used and/or analyzed during the current meta-analysis are available from the corresponding author upon reasonable request.

\section{Declarations}

Ethics approval and consent to participate

Not applicable, as this is a meta-analysis of previously published papers.

\section{Consent for publication}

Not applicable.

\section{Competing interests}

All authors declare that there is no conflict of interest.

Received: 4 October 2020 Accepted: 23 July 2021

Published online: 04 August 2021

\section{References}

1. Huang C, Wang Y, Li X, Ren L, Zhao J, Hu Y, et al. Clinical features of patients infected with 2019 novel coronavirus in Wuhan, China. Lancet. 2020;395(10223):497-506. https://doi.org/10.1016/S0140-6736(20)30183-5. 
2. Wu Z, McGoogan JM. Characteristics of and important lessons from the coronavirus disease 2019 (COVID-19) outbreak in China: summary of a report of 72314 cases from the Chinese Center for Disease Control and Prevention. JAMA. 2020;323(13):1239-42. https://doi.org/10.1001/ja ma.2020.2648

3. Zu ZY, Jiang MD, Xu PP, Chen W, Ni QQ, Lu GM, et al. Coronavirus disease 2019 (COVID-19): a perspective from China. Radiology. 2020;296(2):E15-25. https://doi.org/10.1148/radiol.2020200490.

4. Li Q, Hwang LC. Strategies for selecting/switching chemotherapy and supportive care treatments during COVID-19 outbreak. Cancer Med. 2020; 9(17):6079-81. https://doi.org/10.1002/cam4.3314.

5. Kinross $P$, et al. Rapidly increasing cumulative incidence of coronavirus disease (COVID-19) in the European Union/European economic area and the United Kingdom, 1 January to 15 March 2020. Euro Surveill. 2020;25(11): 2000285. https://doi.org/10.2807/1560-7917.ES.2020.25.11.2000285.

6. Michael DR, Jack AA, Masetti G, Davies TS, Loxley KE, Kerry-Smith J, et al. A randomised controlled study shows supplementation of overweight and obese adults with lactobacilli and bifidobacteria reduces bodyweight and improves well-being. Sci Rep. 2020;10(1):4183. https://doi.org/10.1038/s41 598-020-60991-7.

7. Frydrych LM, Bian G, O'Lone DE, Ward PA, Delano MJ. Obesity and type 2 diabetes mellitus drive immune dysfunction, infection development, and sepsis mortality. J Leukoc Biol. 2018;104(3):525-34. https://doi.org/10.1002/ JLB.5VMR0118-021RR.

8. Talbot HK, Coleman LA, Crimin K, Zhu Y, Rock MT, Meece J, et al. Association between obesity and vulnerability and serologic response to influenza vaccination in older adults. Vaccine. 2012;30(26):3937-43. https:// doi.org/10.1016/j.vaccine.2012.03.071.

9. Dixon $A E$, Peters $U$. The effect of obesity on lung function. Expert Rev Respir Med. 2018;12(9):755-67. https://doi.org/10.1080/17476348.2018.1506331.

10. Zachariah $P$, et al. Epidemiology, Clinical Features, and Disease Severity in Patients With Coronavirus Disease 2019 (COVID-19) in a Children's Hospital in New York City, New York. JAMA Pediatr. 2020;174(10):e202430. https://doi. org/10.1001/jamapediatrics.2020.2430.

11. Zheng Kl, Gao F, Wang XB, Sun QF, Pan KH, Wang TY, et al. Letter to the editor: obesity as a risk factor for greater severity of COVID-19 in patients with metabolic associated fatty liver disease. Metabolism. 2020;108:154244. https://doi.org/10.1016/j.metabol.2020.154244.

12. Huang $R$, Zhu L, Xue L, Liu L, Yan X, Wang J, et al. Clinical findings of patients with coronavirus disease 2019 in Jiangsu province, China: a retrospective, multi-center study. PLoS Negl Trop Dis. 2020;14(5):e0008280. https://doi.org/10.1371/journal.pntd.0008280.

13. Ong $\mathrm{S}$, et al. Association of higher body mass index (BMI) with severe coronavirus disease 2019 (COVID-19) in younger patients. Clin Infect Dis. 2020;71(16):2300-2. https://doi.org/10.1093/cid/ciaa548.

14. Swartz MK. The PRISMA statement: a guideline for systematic reviews and meta-analyses. J Pediatr Health Care. 2011;25(1):1-2. https://doi.org/10.1016/ j.pedhc.2010.09.006.

15. Zhang Z, Wu P, Zhang J, Wang S, Zhang G. The effect of statins on microalbuminuria, proteinuria, progression of kidney function, and all-cause mortality in patients with non-end stage chronic kidney disease: a metaanalysis. Pharmacol Res. 2016;105:74-83. https://doi.org/10.1016/j.phrs.2016. 01.005 .

16. Hernández-Garduño E. Obesity is the comorbidity more strongly associated for Covid-19 in Mexico. A case-control study. Obes Res Clin Pract. 2020;14(4): 375-9. https://doi.org/10.1016/j.orcp.2020.06.001.

17. Bello-Chavolla OY, et al. Predicting Mortality Due to SARS-CoV-2: A Mechanistic Score Relating Obesity and Diabetes to COVID-19 Outcomes in Mexico. J Clin Endocrinol Metab. 2020;105(8):dgaa346. https://doi.org/10.121 0/clinem/dgaa346.

18. de Lusignan S, Dorward J, Correa A, Jones N, Akinyemi O, Amirthalingam G, et al. Risk factors for SARS-CoV-2 among patients in the Oxford Royal College of general practitioners research and surveillance Centre primary care network: a cross-sectional study. Lancet Infect Dis. 2020;20(9):1034-42. https://doi.org/10.1016/S1473-3099(20)30371-6.

19. Lemyze $M$, Courageux N, Maladobry T, Arumadura C, Pauquet $P$, Orfi A, et al. Implications of obesity for the Management of Severe Coronavirus Disease 2019 pneumonia. Crit Care Med. 2020;48(9):e761-7. https://doi.org/1 0.1097/CCM.0000000000004455.

20. Toussie D, Voutsinas N, Finkelstein M, Cedillo MA, Manna S, Maron SZ, et al. Clinical and chest radiography features determine patient outcomes in young and middle-aged adults with COVID-19. Radiology. 2020;297(1):E197206. https://doi.org/10.1148/radiol.2020201754.

21. Elias M, Pievani D, Randoux C, Louis K, Denis B, Delion A, et al. COVID-19 infection in kidney transplant recipients: disease incidence and clinical outcomes. J Am Soc Nephrol. 2020;31(10):2413-23. https://doi.org/10.1 681/ASN.2020050639.

22. Brandt JS, et al. Epidemiology of coronavirus disease 2019 in pregnancy: risk factors and associations with adverse maternal and neonatal outcomes. Am J Obstet Gynecol. 2021;224(4):389.e1-389.e9. https://doi.org/10.1016/j.ajog.2 020.09.043.

23. Wang B, van Oekelen O, Mouhieddine TH, del Valle DM, Richter J, Cho HJ, et al. A tertiary center experience of multiple myeloma patients with COVID-19: lessons learned and the path forward. J Hematol Oncol. 2020; 13(1):94. https://doi.org/10.1186/s13045-020-00934-X.

24. Killerby ME, Link-Gelles R, Haight SC, Schrodt CA, England L, Gomes DJ, et al. Characteristics associated with hospitalization among patients with COVID-19 - metropolitan Atlanta, Georgia, march-April 2020. MMWR Morb Mortal Wkly Rep. 2020;69(25):790-4. https://doi.org/10.1 5585/mmwr.mm6925e1.

25. Hamer M, et al. Lifestyle Risk Factors for Cardiovascular Disease in Relation to COVID-19 Hospitalization: A Community-Based Cohort Study of 387,109 Adults in UK. medRxiv. 2020; https://doi.org/10.1101/2020.05.09.20096438.

26. Price-Haywood EG, Burton J, Fort D, Seoane L. Hospitalization and mortality among black patients and white patients with Covid-19. N Engl J Med. 2020;382(26):2534-43. https://doi.org/10.1056/NEJMsa2011686.

27. Petrilli CM, et al. Factors associated with hospital admission and critical illness among 5279 people with coronavirus disease 2019 in new York City: prospective cohort study. BMJ. 2020;369:m1966.

28. Louapre $\mathrm{C}$, et al. Clinical characteristics and outcomes in patients with coronavirus disease 2019 and multiple sclerosis. JAMA Neurol. 2020; 77(9):1-10.

29. Buckner FS, et al. Clinical features and outcomes of 105 hospitalized patients with COVID-19 in Seattle, Washington.Clin Infect Dis. 2020;71(16): 2167-73. https://doi.org/10.1093/cid/ciaa632.

30. Cai Q, Chen F, Wang T, Luo F, Liu X, Wu Q, et al. Obesity and COVID-19 severity in a designated Hospital in Shenzhen, China. Diabetes Care. 2020; 43(7):1392-8. https://doi.org/10.2337/dc20-0576.

31. Hu L, et al. Risk factors associated with clinical outcomes in 323 COVID-19 hospitalized patients in Wuhan, China. Clin Infect Dis. 2020;71(16):2089-98. https://doi.org/10.1093/cid/ciaa539.

32. Deng M, Qi Y, Deng L, Wang H, Xu Y, Li Z, et al. Obesity as a potential predictor of disease severity in young COVID-19 patients: a retrospective study. Obesity (Silver Spring). 2020;28(10):1815-25. https://doi.org/10.1002/ oby. 22943.

33. Hashemi N, Viveiros K, Redd WD, Zhou JC, McCarty TR, Bazarbashi AN, et al. Impact of chronic liver disease on outcomes of hospitalized patients with COVID-19: a multicentre United States experience. Liver Int. 2020;40(10): 2515-21. https://doi.org/10.1111/liv.14583.

34. Di Bella $\mathrm{S}$, et al. Neck circumference as reliable predictor of mechanical ventilation support in adult inpatients with COVID-19: A multicentric prospective evaluation. Diabetes Metab Res Rev. 2021;37(1):e3354. https:// doi.org/10.1002/dmrr.3354.

35. Hajifathalian K, Kumar S, Newberry C, Shah S, Fortune B, Krisko T, et al. Obesity is associated with worse outcomes in COVID-19: analysis of early Data from new York City. Obesity (Silver Spring). 2020;28(9):1606-12. https:// doi.org/10.1002/oby.22923.

36. Busetto L, Bettini S, Fabris R, Serra R, Dal Pra C, Maffei $P$, et al. Obesity and COVID-19: an Italian snapshot. Obesity (Silver Spring). 2020;28(9):1600-5. https://doi.org/10.1002/oby.22918.

37. Kalligeros $M$, et al. Association of Obesity with Disease Severity Among Patients with Coronavirus Disease 2019. Obesity (silver Spring). 2020;28(7): 1200-4.

38. Simonnet A, Chetboun M, Poissy J, Raverdy V, Noulette J, Duhamel A, et al. High prevalence of obesity in severe acute respiratory syndrome Coronavirus-2 (SARS-CoV-2) requiring invasive mechanical ventilation. Obesity (Silver Spring). 2020;28(7):1195-9. https://doi.org/10.1002/oby.22 831.

39. Nakeshbandi M, Maini R, Daniel P, Rosengarten S, Parmar P, Wilson C, et al. The impact of obesity on COVID-19 complications: a retrospective cohort study. Int J Obes. 2020:44(9):1832-7. https://doi.org/10.1038/s413 66-020-0648-x. 
40. Ortiz-Brizuela E, Villanueva-Reza M, González-Lara MF, Tamez-Torres KM, Román-Montes CM, Díaz-Mejía BA, et al. Clinical and epidemiological characteristics of patients diagnosed with COVID-19 in a tertiary care center in Mexico City: a prospective cohort study. Rev Investig Clin. 2020;72(3):16577. https://doi.org/10.24875/RIC.20000211.

41. Suleyman G, Fadel RA, Malette KM, Hammond C, Abdulla H, Entz A, et al. Clinical characteristics and morbidity associated with coronavirus disease 2019 in a series of patients in metropolitan Detroit. JAMA Netw Open. 2020; 3(6):e2012270. https://doi.org/10.1001/jamanetworkopen.2020.12270.

42. Argenziano MG, et al. Characterization and clinical course of 1000 patients with coronavirus disease 2019 in New York: retrospective case series. BMJ. 2020;369:m1996.

43. Urra JM, Cabrera CM, Porras L, Ródenas I. Selective CD8 cell reduction by SARS-COV-2 is associated with a worse prognosis and systemic inflammation in COVID-19 patients. Clin Immunol. 2020;217:108486. https:// doi.org/10.1016/j.clim.2020.108486.

44. Rottoli M, Bernante P, Belvedere A, Balsamo F, Garelli S, Giannella M, et al. How important is obesity as a risk factor for respiratory failure, intensive care admission and death in hospitalised COVID-19 patients? Results from a single Italian Centre. Eur J Endocrinol. 2020;183(4):389-97. https://doi.org/1 0.1530/EJE-20-0541.

45. Chao JY, et al. Clinical Characteristics and Outcomes of Hospitalized and Critically III Children and Adolescents with Coronavirus Disease 2019 at a Tertiary Care Medical Center in New York City. J Pediatr. 2020;223:14-19.e2.

46. Pettit NN, MacKenzie EL, Ridgway JP, Pursell K, Ash D, Patel B, et al. Obesity is associated with increased risk for mortality among hospitalized patients with COVID-19. Obesity (Silver Spring). 2020;28(10):1806-10. https://doi.org/1 $0.1002 / o b y .22941$.

47. Wu X, et al. Exposure to air pollution and COVID-19 mortality in the United States: A nationwide cross-sectional study. medRxiv. 2020; https://doi.org/1 0.1101/2020.04.05.20054502.

48. Escalera-Antezana JP, Lizon-Ferrufino NF, Maldonado-Alanoca A, Alarcon-dela-Vega G, Alvarado-Arnez LE, Balderrama-Saavedra MA, et al. Risk factors for mortality in patients with coronavirus disease 2019 (COVID-19) in Bolivia: an analysis of the first 107 confirmed cases. Infez Med. 2020;28(2):238-42.

49. Kuderer NM, Choueiri TK, Shah DP, Shyr Y, Rubinstein SM, Rivera DR, et al. Clinical impact of COVID-19 on patients with cancer (CCC19): a cohort study. Lancet. 2020;395(10241):1907-18. https://doi.org/10.1016/S0140-673 6(20)31187-9.

50. Klang E, Kassim G, Soffer S, Freeman R, Levin MA, Reich DL. Severe obesity as an independent risk factor for COVID-19 mortality in hospitalized patients younger than 50. Obesity (Silver Spring). 2020;28(9):1595-9. https://doi.org/1 0.1002/oby.22913.

51. Giacomelli A, Ridolfo AL, Milazzo L, Oreni L, Bernacchia D, Siano M, et al. 30day mortality in patients hospitalized with COVID-19 during the first wave of the Italian epidemic: a prospective cohort study. Pharmacol Res. 2020; 158:104931. https://doi.org/10.1016/j.phrs.2020.104931.

52. Docherty $A B$, et al. Features of 20133 UK patients in hospital with covid-19 using the ISARIC WHO clinical characterisation protocol: prospective observational cohort study. BMJ. 2020;369:m1985.

53. Palaiodimos $L$, et al. Severe obesity, increasing age and male sex are independently associated with worse in-hospital outcomes, and higher inhospital mortality, in a cohort of patients with COVID-19 in the Bronx, New York. Metabolism. 2020;108:154262.

54. Peng Y, Meng K, He M, Zhu R, Guan H, Ke Z, et al. Clinical characteristics and prognosis of 244 cardiovascular patients suffering from coronavirus disease in Wuhan, China. J Am Heart Assoc. 2020;9(19):e016796. https://doi. org/10.1161/JAHA.120.016796.

55. Crespo M, Pérez-Sáez MJ, Redondo-Pachón D, Llinàs-Mallol L, Montero MM, Villar-García J, et al. COVID-19 in elderly kidney transplant recipients. Am J Transplant. 2020;20(10):2883-9. https://doi.org/10.1111/ajt.16096.

56. Chand S, Kapoor S, Orsi D, Fazzari MJ, Tanner TG, Umeh GC, et al. COVID-19associated critical illness-report of the first 300 patients admitted to intensive care units at a new York City medical center. J Intensive Care Med. 2020;35(10):963-70. https://doi.org/10.1177/0885066620946692.

57. Lièvre A, Turpin A, Ray-Coquard I, le Malicot K, Thariat J, Ahle G, et al. Risk factors for coronavirus disease 2019 (COVID-19) severity and mortality among solid cancer patients and impact of the disease on anticancer treatment: a French nationwide cohort study (GCO-002 CACOVID-19). Eur J Cancer. 2020;141:62-81. https://doi.org/10.1016/j. ejca.2020.09.035.
58. Fuster JJ, Ouchi N, Gokce N, Walsh K. Obesity-induced changes in adipose tissue microenvironment and their impact on cardiovascular disease. Circ Res. 2016;118(11):1786-807. https://doi.org/10.1161/CIRCRESAHA.115.306885.

59. Messina $G$, et al. Functional Role of Dietary Intervention to Improve the Outcome of COVID-19: A Hypothesis of Work. Int J Mol Sci. 2020;21(9):3104. https://doi.org/10.3390/ijms21093104.

60. Salvator H, Grassin-Delyle S, Naline E, Brollo M, Fournier C, Couderc L, et al. Contrasting effects of Adipokines on the cytokine production by primary human bronchial epithelial cells: inhibitory effects of adiponectin. Front Pharmacol. 2020;11:56. https://doi.org/10.3389/fphar.2020.00056.

61. Ali AN, Sood A. Leptin, adiponectin and pulmonary diseases. Biochimie. 2012;94(10):2180-9.

62. Dallinga-Thie GM, Dullaart RP. Do genome-wide association scans provide additional information on the variation of plasma adiponectin concentrations? Atherosclerosis. 2010;208(2):328-9. https://doi.org/10.1016/ j.atherosclerosis.2009.12.014.

63. Gómez-Ambrosi J, Salvador J, Silva C, Pastor C, Rotellar F, Gil M, et al. Increased cardiovascular risk markers in obesity are associated with body adiposity: role of leptin. Thromb Haemost. 2006;95(6):991-6. https://doi. org/10.1160/TH06-02-0079.

64. Luzi L, Radaelli MG. Influenza and obesity: its odd relationship and the lessons for COVID-19 pandemic. Acta Diabetol. 2020;57(6):759-64. https:// doi.org/10.1007/s00592-020-01522-8.

65. Kassir R. Risk of COVID-19 for patients with obesity. Obes Rev. 2020;21(6): e13034. https://doi.org/10.1111/obr.13034.

66. De Jong A, Verzilli D, Jaber S. ARDS in obese patients: specificities and management. Crit Care. 2019;23(1):74. https://doi.org/10.1186/s13054-01 9-2374-0.

67. Shore SA. Environmental perturbations: obesity. Compr Physiol. 2011;1(1): 263-82. https://doi.org/10.1002/cphy.c100017.

68. Hariyanto TI, Kurniawan A. Obstructive sleep apnea (OSA) and outcomes from coronavirus disease 2019 (COVID-19) pneumonia: a systematic review and meta-analysis. Sleep Med. 2021;82:47-53. https://doi.org/10.1016/j. sleep.2021.03.029.

69. Gami AS, Caples SM, Somers VK. Obesity and obstructive sleep apnea. Endocrinol Metab Clin N Am. 2003;32(4):869-94. https://doi.org/10.1016/ S0889-8529(03)00069-0.

70. Romero-Corral A, Caples SM, Lopez-Jimenez F, Somers VK. Interactions between obesity and obstructive sleep apnea: implications for treatment. Chest. 2010;137(3):711-9. https://doi.org/10.1378/chest.09-0360.

71. Cauberghe $V$, et al. How adolescents use social media to cope with feelings of loneliness and anxiety during COVID-19 lockdown. Cyberpsychol Behav Soc Netw. 2021;24(4):250-7. https://doi.org/10.1089/cyber.2020.0478.

72. Bhasker AG, Greve JW. Are patients suffering from severe obesity getting a raw Deal during COVID-19 pandemic? Obes Surg. 2020;30(10):4107-8. https://doi.org/10.1007/s11695-020-04677-z.

73. Hawkley LC, Thisted RA, Cacioppo JT. Loneliness predicts reduced physical activity: cross-sectional \& longitudinal analyses. Health Psychol. 2009;28(3): 354-63. https://doi.org/10.1037/a0014400.

74. Drewnowski A. The cost of US foods as related to their nutritive value. Am J Clin Nutr. 2010;92(5):1181-8. https://doi.org/10.3945/ajcn.2010.29300.

75. Hall KD, et al. Ultra-Processed Diets Cause Excess Calorie Intake and Weight Gain: An Inpatient Randomized Controlled Trial of Ad Libitum Food Intake. Cell Metab. 2019;30(1):67-77.e3.

76. Jensen MD, et al. AHA/ACC/TOS guideline for the management of overweight and obesity in adults: a report of the American College of Cardiology/American Heart Association task force on practice guidelines and the Obesity Society. J Am Coll Cardiol. 2014;63(25 Pt B):2985-3023.

77. Egger G. Helping patients lose weight--what works? Aust Fam Physician. 2008;37(1-2):20-3.

78. Kruger J, Galuska DA, Serdula MK, Jones DA. Attempting to lose weight: specific practices among U.S. adults. Am J Prev Med. 2004;26(5):402-6. https://doi.org/10.1016/j.amepre.2004.02.001.

79. Bish CL, Blanck HM, Maynard LM, Serdula MK, Thompson NJ, Khan LK. Health-related quality of life and weight loss practices among overweight and obese US adults, 2003 behavioral risk factor surveillance system. MedGenMed. 2007;9(2):35.

80. Sharma S, Ray A, Sadasivam B. Metformin in COVID-19: a possible role beyond diabetes. Diabetes Res Clin Pract. 2020;164:108183. https://doi.org/1 0.1016/j.diabres.2020.108183. 
81. Ursini F, Ciaffi J, Landini MP, Meliconi R. COVID-19 and diabetes: is metformin a friend or foe? Diabetes Res Clin Pract. 2020;164:108167. https:// doi.org/10.1016/j.diabres.2020.108167.

82. Singh AK, Gupta R, Ghosh A, Misra A. Diabetes in COVID-19: prevalence, pathophysiology, prognosis and practical considerations. Diabetes Metab Syndr. 2020;14(4):303-10. https://doi.org/10.1016/j.dsx.2020.04.004

83. Hui F, Zhang Y, Ren T, Li X, Zhao M, Zhao Q. Role of metformin in overweight and obese people without diabetes: a systematic review and network meta-analysis. Eur J Clin Pharmacol. 2019;75(4):437-50. https://doi. org/10.1007/s00228-018-2593-3.

84. Stanton R, et al. Depression, Anxiety and Stress during COVID-19: Associations with Changes in Physical Activity, Sleep, Tobacco and Alcohol Use in Australian Adults. Int J Environ Res Public Health. 2020;17(11):4065. https://doi.org/10.3390/ijerph17114065.

85. Moynihan $\mathrm{AB}$, et al. Eaten up by boredom: consuming food to escape awareness of the bored self. Front Psychol. 2015;6:369.

\section{Publisher's Note}

Springer Nature remains neutral with regard to jurisdictional claims in published maps and institutional affiliations.

Ready to submit your research? Choose BMC and benefit from:

- fast, convenient online submission

- thorough peer review by experienced researchers in your field

- rapid publication on acceptance

- support for research data, including large and complex data types

- gold Open Access which fosters wider collaboration and increased citations

- maximum visibility for your research: over $100 \mathrm{M}$ website views per year

At BMC, research is always in progress.

Learn more biomedcentral.com/submissions 